\title{
Urgensi Program Pengungkapan Sukarela (Tax Amnesty Jilid II) Berdasarkan Sudut Pandang Wajib Pajak
}

\author{
Adinda Suci Cahya Ningtyas ${ }^{1 *}$, Aisyaturrahmi ${ }^{2}$ \\ 1,2Program Studi Akuntansi Universitas Negeri Surabaya \\ *Coresponding author: adindakurniawan99@gmail.com | Phone Number: 085731426955 \\ DOI: https://doi.org/10.29103/jak.v10i1.6611
}

\section{ARTICLE INFO}

Received: 17-02-2022

Received in revised: 21-02-2022

Accepted: 23-02-2022

Available online: 01-03-2022

\section{KEYWORDS}

Voluntary Disclosure Program;

Taxpayer Perception;

Goverment Trust;

\section{A B S T R A C T}

The purpose of this study is to examine and analyze the effect of the Voluntary Disclosure Program (VDP) on the perception of taxpayers, and is moderated by government trust. The data collection technique used in this study is convenience sampling. This study used a sample of 115 respondents from KPP Pratama Surabaya Mulyorejo. The data used are primary data obtained through questionnaires and interviews with taxpayers. The data analysis technique used validity, reliability, classical assumptions and MRA (Moderated Regression Analysis). The results of the research based on hypothesis testing, namely the Voluntary Disclosure Program (X) partially statistically has an influence on the Taxpayer Perception (Y) and moderated by the Government Trust (Z) can strengthen the influence between the regression models.

\section{PENDAHULUAN}

Coronavirus Disease-19 yang dialami oleh seluruh dunia masih terus berlanjut bahkan kasus di Indonesia sendiri kian meningkat. Pandemi ini membawa banyak sekali perubahan dalam tatanan kehidupan baik dari segi bermasyarakat hingga negara. Diterapkannya pembatasan kegiatan masyarakat menghambat kegiatan sosial ekonomi masyarakat. Selain itu, akibat pendemi yang berkepanjangan ini stabilitas ekonomi Indonesia mulai terganggu. Pada tahun 2020 pasca pandemic covid-19, Indonesia mengalami resesi ekonomi. Resesi ekonomi di Indonesia salah satunya, ditandai dengan meningkatnya angka pengangguran. Per Agustus 2020 tercatat angka pengangguran sebesar 7,07\% mengalami peningkatan sebesar 1,84\% dibandingkan dengan Agusus 2019 (BPS, 2020). Pemerintah Indonesia telah mengupayakan untuk memulihkan kembali perekonomian dengan mengeluarkan Perpu tentang kebijakan keuangan negara dalam hal menangani pandemi covid-19 sebagai upaya untuk menstabilkan ekonomi negara. Perpu tersebut juga memuat kebijakan terkait penerimaan negara di bidang perpajakan. Dilansir dari Masdi (2021) Indonesia mengalami penurunan penerimaan pajak di tahun 2020 sebesar 19,6\% dibanding tahun 2019. Realisasi penerimaan pajak tahun 2020 hanya sebesar 89,4\%dari target APBN sehingga dapat dikatakan adanya shortfall atau tidak tercapainya target sekitar 126,7 triliun. Akibatnya, defisit anggaran mengalami kenaikan menjadi 6,1\% dari PDB.

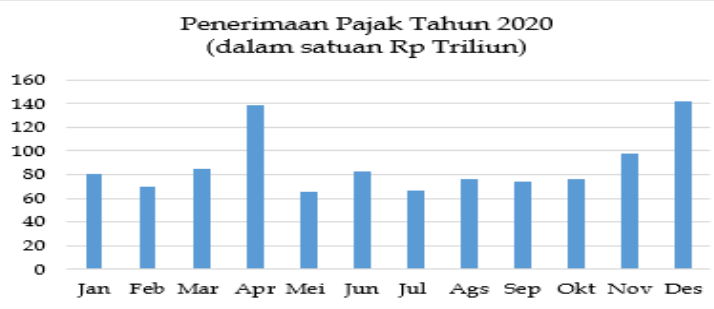

Gambar 1. Penerimaan Pajak Tahun 2020 (bulan demi bulan)

Sumber: APBN Kinerja dan Fakta Edisi Januari 2021 
Pajak dapat dikatakan sebagai penopang atau tumpuan dalam penerimaan negara. Penerimaan tersebut akan digunakan untuk membiayai segala kebutuhan negara seperti pembangunan, pendidikan, dan kesehatan (Alfiyah \& Latifah, 2017). Rencana pemerintah dalam meningkatkan penerimaan negara melalui sektor perpajakan dalam waktu dekat ini dapat terlihat dari munculnya pemberitaan terkait Tax Amnesty Jilid II atau saat ini disebut dengan Program Pengungkapan Sukarela yang dilaksanakan pada tahun 2022. Menurut pernyataan Menteri Keuangan Republik Indonesia (2021) Program Pengungkapan Sukarela adalah suatu kebijakan yang memberikan pilihan kepada wajib pajak untuk dapat mengungkapkan harta dan kewajiban perpajakannya yang belum diungkapkan secara sukarela. Program pengungkapan sukarela ini merupakan kebijakan yang bukan hanya pengampunan pajak namun juga kesempatan langka yang dapat dimanfaatkan sebaik mungkin oleh wajib pajak.

Upaya meningkatkan penerimaan negara sektor perpajakan akan optimal jika didukung dengan perilaku patuh wajib pajak. Salah satu teori yang mengkaji perilaku wajib pajak yaitu Teori Perilaku Terencana (TPB). Menurut Suliyawanti (2018) teori ini berkaitan dengan model psikologis sosial manusia yang bermanfaat dalam menjelaskan tingkah laku manusia secara spesifik. Tingkah laku manusia didukung dengan niat dari masing-masing individu. Niat berfungsi sebagai motivasi yang dapat mempengaruhi perilaku manusia. Untuk itu, teori ini dapat mendukung perilaku wajib pajak bersikap patuh terhadap kewajiban perpajakannya sehingga penerimaan negara akan meningkat terutama dalam sektor perpajakan.

Kebijakan Program Pengungkapan Sukarela tidak dapat berjalan dengan sukses tanpa adanya kontribusi wajib pajak. Program Pengungkapan Sukarela memberikan opsi kepada wajib pajak yang belum sepenuhnya melaporkan hartanya di masa lalu untuk mengikuti kebijakan tersebut dengan membayar sesuai tarif PPH atas pengungkapan harta yang dilaporkan. Pengambilan opsi oleh wajib pajak tergantung pada persepsi masing-masing individu dalam menyikapi kebijakan Program Pengungkapan Sukarela ini. Persepsi wajib pajak terkait Program Pengungkapan Sukarela dinilai sangat penting dalam mendukung terlaksananya kebijakan ini dikarenakan pelaku dari program pengungkapan sukarela adalah wajib pajak itu sendiri. Faktor pendukung terbentuknya persepsi wajib pajak dapat berupa sikap, motivasi, harapan, pengalaman, suasana, dan suatu hal yang baru (Aruan, Sujana, \& Tripalupi, 2017). Faktor pendukung penting lainnya dalam pembentukan persepsi wajib pajak yaitu kepercayaan terhadap pemerintah dalam melaksanakan kebijakan tersebut.

Kepercayaan wajib pajak terhadap pemerintah akan mempengaruhi perilaku untuk mendukung atau tidak mendukung Program Pengungkapan Sukarela. Berdasarkan penelitian yang telah dilakukan oleh Doğan Bozdoğan (2018) di negara Turki, menyatakan bahwa tax amnesty yang terlalu sering dilaksanakan justru dapat merugikan negara sehingga atas hal ini pemerintah perlu menyiapkan sistem pemerintahan dan hukum perpajakan yang baik agar menumbuhkan rasa percaya serta rasa aman bagi wajib pajak. Ketika hukum perpajakan dan sistem pemerintahan telah baik wajib pajak akan merasa yakin terhadap pajak yang mereka bayarkan tidak akan disalahgunakan. Hal ini menandakan bahwa kepercayaan terhadap pemerintah merupakan suatu perilaku yang dapat berpengaruh terhadap pengambilan keputusan dalam memenuhi kewajiban perpajakan (Purnamasari, 2017 dalam Dewi \& Diatmika 2020). Penelitian Sipahutar \& Siringoringo (2019) menjelaskan bahwa persepsi wajib pajak untuk mengikuti program tax amnesty dipengaruhi oleh kepercayaan terhadap pemerintah dengan syarat pemerintah harus menjamin keadilan dan kesetaraan hukum bagi seluruh wajib pajak yang mengikuti. Penelitian yang dilakukan oleh Dewi \& Diatmika (2020) juga mendukung penelitian dari Sipahutar \& Siringoringo (2019) yang menjelaskan bahwa kepercayaan terhadap pemerintah akan meningkat jika persepsi wajib pajak terkait sistem dan hukum perpajakan di Indonesia telah terlaksana dengan baik sehingga hal ini juga akan meningkatkan angka kepatuhan wajib pajak. Atas hal tersebut, kepercayaan terhadap pemerintah menjadi salah satu faktor dalam keberhasilan Program Pengungkapkan Sukarela yang mulai dilaksanakan di tahun 2022 ini.

Berdasarkan penjelasan diatas, penelitian ini memiliki tujuan untuk menguji dan menganalisis mengenai pengaruh Program Pengungkapan Sukarela terhadap Persepsi Wajib Pajak, serta pengaruh Program Pengungkapan Sukarela terhadap Persepsi Wajib Pajak yang dimoderasi oleh Kepercayaan Terhadap Pemerintah. Penelitian ini berfokus pada wajib pajak orang pribadi di wilayah Surabaya. Penelitian ini dapat dijadikan evaluasi bagi pemerintah untuk kebijakan yang akan dibuat kedepannya, atas evaluasi tersebut pemerintah kedepannya dapat berinovasi untuk memenuhi target penerimaan negara dari perpajakan melalui kebijakan yang akan ditetapkan. Penelitian ini juga berkontribusi dalam mengedukasi wajib pajak agar dapat mengikuti kebijakan Program Pengungkapan Sukarela ini. Harapannya ketika wajib pajak tertarik untuk mengikuti maka penerimaan negara juga akan meningkat.

\section{TINJAUAN PUSTAKA}

\section{Theory of Planned Behavior}

Teori psikologis yang biasanya digunakan untuk meramalkan perilaku individu dikenal dengan Teori Perilaku Terencana. Teori Perilaku Terencana dirumuskan oleh Ajzen (1991) yang menjelaskan bahwa niat merupakan kunci penting setiap individu untuk melakukan perilaku tertentu. Niat dapat dikatakan sebagai pendorong yang dapat mempengaruhi perilaku serta mengukur seberapa besar keinginan seseorang untuk melakukan perilaku tersebut, sehingga jika seseorang 
memiliki niat yang tinggi maka semakin besar peluang untuk mencapai perilaku yang diinginkan. Sikap, norma subjektif, dan kontrol perilaku yang dipersepsikan adalah tiga komponen utama dalam Teori Perilaku Terencana (TPB).

Ajzen (1991) menjelaskan bahwa TPB masih dapat ditambahkan dengan komponen lain sesuai dengan objek yang diteliti. Penambahan komponen ini bertujuan untuk menjelaskan perilaku yang dapat mempengaruhi niat lebih baik lagi. Atas hal ini, peneliti akan menambahkan satu komponen yakni kewajiban moral yang diharapkan dapat mempengaruhi niat wajib pajak untuk mengikuti program pengungkapan sukarela. Kewajiban moral dipilih dengan mempertimbangkan kewajiban setiap warga negara Indonesia. Kewajiban warga negara indonesia salah satunya yakni mematuhi hukum dan pemerintahan. Hukum ini juga termasuk hukum perpajakan di Indonesia, sehingga kewajiban sebagai warga negara Indonesia yakni memenuhi kewajiban perpajakannya sesuai dengan ketentuan yang berlaku.

\section{Teori Atribusi}

Teori perilaku yang meramalkan perilaku dengan melihat faktor internal dan faktor eksternal dikenal dengan teori atribusi. Kedua faktor ini akan mempengaruhi seseorang dalam mengambil keputusan (Ariesta \& Latifah, 2017). Faktor internal berasal dari diri individu sendiri seperti sifat, karakter, usia dan pendidikan sedangkan faktor eksternal berasal dari lingkungan luar seperti keadaan ekonomi global. Hal ini dapat diartikan sebagai perilaku keterpaksaan individu akibat adanya tekanan situasi (Wijaya \& Febrianti, 2021).

\section{Program Pengungkapan Sukarela}

Program pengungkapan sukarela merupakan kebijakan baru di bidang perpajakan yang dikeluarkan oleh pemerintah. Kebijakan ini tidak hanya memberikan pengampunan pajak namun juga memberikan pilihan kepada wajib pajak untuk melaporkan hartanya yang belum dilaporkan di masa lalu secara sukarela dengan membayar PPH sebesar pelaporan harta tersebut. Program pengungkapan sukarela dilaksanakan pada 1 Januari - 30 Juni 2022. Berdasarkan UU HPP, terdapat 2 skema program pengungkapan sukarela, antara lain (UU HPP, 2021):

\section{Tabel 1. Skema Program Pengungkapan Sukarela}

\begin{tabular}{|c|c|c|}
\hline Keterangan & Kebijakan 1 & Kebijakan 2 \\
\hline Subyek & $\begin{array}{l}\text { WP OP dan Badan } \\
\text { Peserta TA }\end{array}$ & WP OP \\
\hline Basis Aset & Aset per 31 Desember 2015 & $\begin{array}{l}\text { Aset Perolehan tahun 2016-2020 yang belum } \\
\text { dilapor di SPT tahunan } 2020\end{array}$ \\
\hline Tarif PPh Final & $\begin{array}{l}\text { - } 11 \% \text { untuk aset LN } \\
\text { - } 8 \% \text { untuk aset repatriasi LN dan aset DN } \\
\text { - } 6 \% \text { untuk aset repatriasi LN dan aset DN yang } \\
\text { di investasikan ke SBN/hiliirisasi/renewable } \\
\text { energy. }\end{array}$ & $\begin{array}{l}\text { - } 18 \% \text { untuk aset LN } \\
\text { - } 14 \% \text { untuk aset repartisasi LN dan aset DN } \\
\text { - } 12 \% \text { untuk aset repatriasi LN dan aset DN yang } \\
\text { diinvestasikan ke SBN/hilirisasai/renewable } \\
\text { energy. }\end{array}$ \\
\hline
\end{tabular}

Sumber: Data diolah oleh peneliti (2022)

\section{Persepsi Wajib Pajak}

Persepsi merupakan suatu interpretasi dari peristiwa yang akan terjadi pada setiap individu dalam memaknai informasi di sekitar lingkungannya melalui penglihatan, perasaan, penghayatan dan penciuman (Mangumban, 2015 dalam Irawati \& Sari 2019). Persepsi wajib pajak yang positif terhadap kewajiban perpajakannya akan mempengaruhi perilaku wajib pajak tersebut dalam memenuhi kewajibannya. Namun sebaliknya jika persepsi wajib pajak negatif terhadap kewajiban perpajakannya maka perilaku wajib pajak tersebut akan menunjukkan ketidakpatuhan.

Persepsi wajib pajak terkait kebijakan program pengungkapan sukarela merupakan sebuah pandangan, tafsiran, interpretasi, atau anggapan dari masing-masing wajib pajak mengenai kebijakan tersebut (Suyanto \& Putri, 2017). Persepsi tidak terbentuk begitu saja melainkan melalui beberapa tahapan atau proses dengan di dukung faktor-faktor pembentukannya seperti pengetahuan terkait program pengungkapan sukarela dan pendapat dari kerabat terdekat. Perilaku wajib pajak akan 
sangat dipengaruhi oleh persepsi wajib pajak itu sendiri sehingga pembentukan persepsi menjadi poin penting bagi wajib pajak sebelum melakukan suatu tindakan.

\section{Kepercayaan Terhadap Pemerintah}

Menurut KBBI, kepercayaan adalah suatu keyakinan terhadap suatu hal yang dipercayai bersifat nyata atau benar. Kirana \& Moordiningsih (2010) dalam Sipahutar \& Siringoringo (2019) menjelaskan bahwa membangun kepercayaan bukan hal yang mudah. Kepercayaan dapat terbentuk melalui pengalaman masa lalu seseorang, pengalaman yang memberikan kesan baik dapat menunjang terbentuknya rasa saling percaya dan komitmen bersama.

Kepercayaan antara wajib pajak dan pemerintah seharusnya terjalin dengan baik karena rasa saling percaya akan memberikan dorongan kepada wajib pajak untuk bersikap patuh. Di samping itu, kepercayaan wajib pajak kepada pemerintah terwujud melalui kepatuhan serta harapan agar dapat menjalankan pemerintahan dengan baik sesuai dengan norma yang berlaku (Purnamasari, Pratiwi, \& Sukirman, 2018).

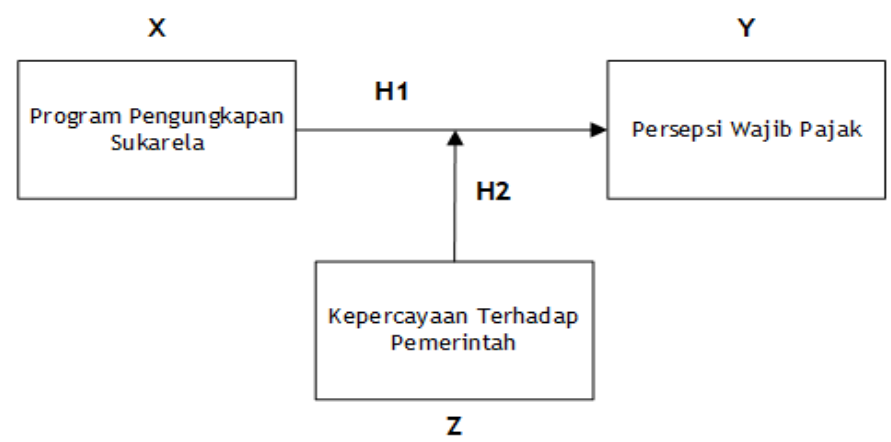

Gambar 2. Model Penelitian

\section{Perumusan Hipotesis}

Pengaruh Program Pengungkapan Sukarela terhadap Persepsi Wajib Pajak

Program pengungkapan sukarela dengan persepsi wajib pajak memiliki keterkaitan. Berdasarkan teori perilaku terencana, menjelaskan bahwa setiap perilaku individu selalu diawali dengan niat. Wajib pajak dapat membentuk niat dalam menentukan perilaku atau persepsinya melalui sikap, dorongan dari orang terdekat, pengetahuan dan pengalaman masa lalu, maupun kewajiban moralnya. Seluruh faktor tersebut akan menghasilkan persepsi wajib pajak yang akan digunakan dalam pengambilan keputusan untuk mengikuti atau mendukung program pengungkapan sukarela atau tidak.

Selain itu berdasarkan teori atribusi, faktor eksternal yang memberikan pengaruh kepada persepsi wajib pajak untuk bersikap patuh yakni program pengungkapan sukarela (Alfiyah \& Latifah, 2017). Dengan demikian, terdapat indikasi program pengungkapan sukarela memiliki hubungan dengan persepsi wajib pajak karena dapat menentukan suatu perilaku wajib pajak. Dari penjelasan diatas hipotesis yang diajukan yakni:

\section{H1 : Program Pengungkapan Sukarela berpengaruh terhadap Persepsi Wajib Pajak.}

\section{Pengaruh Program Pengungkapan Sukarela terhadap Persepsi Wajib Pajak yang dimoderasi Kepercayaan Terhadap Pemerintah}

Penggunaan theory of planned behavior akan menghasilkan pemikiran yang rasional. Hal ini berguna bagi wajib pajak dalam pengambilan keputusan untuk berperilaku terutama dalam menjalankan kewajiban perpajakannya (Purnamasari et al., 2018). Berdasarkan teori atribusi, kepercayaan terhadap pemerintah menjadi faktor eksternal yang dapat mempengaruhi perilaku atau persepsi wajib pajak (Ketut, Ambara, \& Noviari, 2017). Hal ini dikarenakan pemerintah memiliki peran penting dalam mendukung keberhasilan kebijakan program pengungkapan sukarela. Pemerintah selaku pihak berwenang yang bertanggungjawab dalam pembuatan kebijakan program pengungkapan sukarela seharusnya dapat memberikan kepercayaan kepada wajib pajak terkait kebijakan baru yang dikeluarkannya merupakan kebijakan yang baik, sehingga persepsi wajib pajak akan positif terhadap program pengungkapan sukarela, namun jika pemerintah gagal menumbuhkan rasa percaya wajib pajak, maka akan timbul persepsi yang sebaliknya. Dari penjelasan diatas hipotesis yang diajukan yakni:

\section{H2 : Kepercayaan Terhadap Pemerintah dapat memperkuat pengaruh Program Pengungkapan Sukarela terhadap Persepsi Wajib Pajak.}

\section{METODE PENELITIAN}

\section{Populasi dan Sampel}

Populasi dalam penelitian yaitu seluruh wajib pajak yang terdaftar di Kantor Pelayanan Pajak Kota Surabaya. Sampel dalam penelitian yakni 115 wajib pajak yang berasal dari KPP Pratama Surabaya Mulyorejo. Penelitian ini menggunakan convenience 
sampling yang merupakan teknik sampling dengan asas kemudahan dalam pengambilan sampel seperti orang-orang yang mudah ditemui dan dijangkau. Penelitian ini menggunakan data primer yang diperoleh melalui penyebaran kuesioner dan wawancara kepada wajib pajak orang pribadi. Pengukuran hasil kuesioner diukur menggunakan skala likert sesuai dengan variabel penelitian. Data hasil wawancara kepada empat wajib pajak orang pribadi akan digunakan untuk memperkuat hasil kuesioner dan mendapat perbandingan jawaban antar informan. Empat wajib pajak orang pribadi ini dikelompokkan dalam dua kategori yakni:

1. Dua WPOP dengan persepsi positif terhadap program pengungkapan sukarela.

2. Dua WPOP dengan persepsi negatif terhadap program pengungkapan sukarela.

\section{Definisi Operasional dan Indikator Pengkuran Variabel}

\section{Variabel Dependen (Y) : Persepsi Wajib Pajak}

Persepsi wajib pajak merupakan pandangan atau pemikiran wajib pajak terhadap suatu kebijakan, peraturan dan peristiwa perpajakan yang terjadi. Berikut indikator untuk mengukur persepsi wajib pajak (Ajzen, 1991):
a. Sikap
b. Norma Subjektif
c. Kontrol Perilaku yang dipersepsikan
d. Kewajiban Moral

\section{Variabel Independen (X) : Program Pengungkapan Sukarela}

Program pengungkapan sukarela merupakan suatu kebijakan yang dapat dimanfaatkan oleh wajib pajak untuk melaporkan hartanya yang belum terlapor dimasa lalu dengan membayar pajak sesuai tarif yang telah ditentukan. Wajib pajak yang mengikuti kebijakan ini juga akan terhindar dari pemeriksaan oleh fiskus serta sanksi administratif yang lebih besar. Indikator pengukuran program pengungkapan sukarela diasumsikan sama dengan indikator pengukuran tax amnesty (Ariesta \& Latifah, 2017):
a. Pengetahuan
b. Pemahaman
c. Kesadaran dan motivasi
d. Pemanfaatan

\section{Variabel Moderasi (Z) : Kepercayaan Terhadap Pemerintah}

Kepercayaan terhadap pemerintah merupakan keyakinan wajib pajak terhadap pemangku kebijakan yang juga bertanggungjawab atas suatu kebijakan. Berikut indikator untuk mengukur kepercayaan terhadap pemerintah Handayani (2012) dalam (Purnamasari et al., 2018):
a. Sistem pemerintahan
b. Sistem hukum
c. Politisi
d. Hak rakyat

\section{HASIL DAN PEMBAHASAN}

Uji Validitas

Tabel 2. Hasil Uji Validitas Variabel X

\begin{tabular}{|c|c|c|c|}
\hline Indikator & Nilai r Hitung & Nilai r Tabel & \multirow{2}{*}{ Keterangan } \\
\hline X1.1 &, 773 &, 183 & \\
\hline $\mathrm{X} 1.2$ &, 770 &, 183 & \\
\hline $\mathrm{X} 1.3$ &, 811 &, 183 & \\
\hline $\mathrm{X} 1.4$ &, 741 &, 183 & \\
\hline $\mathrm{X} 1.5$ &, 726 &, 183 & \\
\hline
\end{tabular}

Sumber: Data primer yang diolah, 202 
Tabel 3. Hasil Uji Validitas Variabel Y

\begin{tabular}{|c|c|c|c|}
\hline Indikator & Nilai r Hitung & Nilai r Tabel & Keterangan \\
\hline Y1.1 & 455 & ,183 & \multirow[t]{14}{*}{ Valid } \\
\hline Y1.2 & ,504 & ,183 & \\
\hline Y1.3 & ,604 & 183 & \\
\hline Y1.4 & ,578 & 183 & \\
\hline Y2.1 & ,367 & 183 & \\
\hline Y2.2 & , 435 & , 183 & \\
\hline Y2.3 & ,420 & 183 & \\
\hline Y2.4 & ,482 & 183 & \\
\hline Y3.1 & ,543 & , 183 & \\
\hline Y3.2 & ,379 & 183 & \\
\hline Y3.3 & ,401 & 183 & \\
\hline Y4.1 & 452 & 183 & \\
\hline Y4.2 & ,560 & 183 & \\
\hline Y4.3 & 510, & 183, & \\
\hline
\end{tabular}

Sumber: Data primer yang diolah, 2022

Tabel 4. Hasil Uji Validitas Variabel Z

\begin{tabular}{|c|c|c|c|}
\hline Indikator & Nilai r Hitung & Nilai r Tabel & Keterangan \\
\hline Z1.1 &, 858 &, 183 & \multirow{2}{*}{ Valid } \\
\hline Z1.2 &, 897 &, 183 & \\
\hline Z1.3 &, 893 &, 183 & \\
\hline Z1.4 &, 816 &, 183 & \\
\hline Z1.5 &, 740 & & \\
\hline
\end{tabular}

Sumber: Data primer yang diolah, 2022

Syarat penentuan validitas untuk setiap indikator yakni dengan melakukan perbandingan antara nilai $r$ tabel dengan nilai $r$ hitung. Penentuan nilai $r$ tabel dengan jumlah data 115 dan tingkat signifikansi 0,05 yakni sebesar nilai $(d f)=n-2$ yaitu $r(115$ - 2 $=113)=0,183$ pada $r$ tabel. Data dikatakan valid jika nilai $r$ hitung $>r$ tabel, hasil pengujian yang didapatkan pada Tabel 2,3 dan 4 untuk setiap indikator menunjukkan nilai $r$ hitung $>r$ tabel sehingga data dinyatakan valid.

\section{Uji Reliabilitas}

Tabel 5. Hasil Uji Reliabilitas

\begin{tabular}{|c|c|c|c|}
\hline Variabel & $\begin{array}{c}\text { Nilai Cronbach } \\
\text { Alpha }\end{array}$ & Syarat Pengujian & Keterangan \\
\hline X &, 817 &, 60 & \multirow{2}{*}{ Reliabel } \\
\hline Y &, 740 &, 60 & \\
\hline Z &, 897 &, 60 & \\
\hline
\end{tabular}

Sumber: Data primer yang diolah, 2022

Berdasarkan Janna (2020) dan V. Wiratna Sujarweni (2015) pengujian reliabilitas dengan SPSS melihat nilai crounbach's alpha. Syarat pengujian ini yakni jika nilai nilai crounbach's alpha $>0,60$, maka dikatakan reliabel. Hasil yang didapatkan pada Tabel 5 menunjukkan bahwa nilai crounbach's alpha >0,60 sehingga data penelitian ini dinyatakan reliabel. 


\section{Uji Normalitas}

Tabel 6. Hasil Uji Normalitas

\begin{tabular}{|l|l|r|}
\hline \multicolumn{2}{|c|}{ One-Sample Kolmogorov-Smirnov Test } \\
\hline$N$ & $\begin{array}{c}\text { Unstandardized } \\
\text { Residual }\end{array}$ \\
\hline Normal Parameters ${ }^{a, b}$ & Mean &, 0000000 \\
\hline \multicolumn{2}{|c|}{ Std. Deviation } & 4,48732528 \\
\hline Most Extreme Differences & Absolute &, 076 \\
\hline \multicolumn{2}{|c|}{ Positive } &,- 042 \\
\hline \multicolumn{2}{|c|}{ Negative } &, 076 \\
\hline Test Statistic & &, $113^{c}$ \\
\hline Asymp. Sig. (2-tailed)
\end{tabular}

Sumber: Data primer yang diolah, 2022

Syarat pengujian normalitas yakni data dikatakan normal jika nilai (Sig) > 0,05. Hasil yang didapatkan pada Tabel 6 menunjukkan nilai (Sig) sebesar 0,113>0,05 sehingga data penelitian telah terdistribusi secara normal dan dapat diolah.

Uji Multikolinearitas

Tabel 7. Hasil Uji Multikolinearitas

\begin{tabular}{|c|c|c|c|c|c|}
\hline \multicolumn{2}{|c|}{ Model } & \multirow{3}{*}{$\begin{array}{l}\mathbf{T} \\
11,289\end{array}$} & \multirow{3}{*}{$\begin{array}{l}\text { Sig. } \\
, 000\end{array}$} & \multicolumn{2}{|c|}{ Collinearity Statistics } \\
\hline & & & & \multirow[t]{2}{*}{ Tolerance } & \multirow[t]{2}{*}{ VIF } \\
\hline 1 & (Constant) & & & & \\
\hline & TOTAL_X & 3,874 &, 000 & ,656 & 1,525 \\
\hline & TOTAL_Z & 3,393 & 001 & 656 & 1,525 \\
\hline
\end{tabular}

Sumber: Data primer yang diolah, 2022

Dikatakan terbebas dari masalah multikolinearitas yaitu nilai tolerance $>0,1$ dan nilai VIF $<10$. Hasil yang didapatkan pada Tabel 7 menunjukkan nilai tolerance sebesar 0,656 0,1 serta nilai VIF sebesar 1,525 < 10 sehingga model regresi dikatakan terbebas dari masalah multikolinearitas.

Uji Heterokedastisitas

Tabel 8. Hasil Uji Heterokedastisitas

\begin{tabular}{|l|l|r|r|r|r|r|}
\hline \multicolumn{2}{|l|}{ Model } & \multicolumn{2}{|c|}{ Unstandardized Coefficients } & Standardized Coefficients & \multirow{2}{*}{ Sig. } \\
\cline { 3 - 8 } & B & Std. Error & Beta & & \\
\hline \multirow{2}{*}{1} & (Constant) & 3,332 & 1,809 & & 1,842 &, 068 \\
\cline { 2 - 7 } & TOTAL_X &, 030 &, 107 &, 033 &, 282 &, 778 \\
\cline { 2 - 7 } & TOTAL_Z &,- 026 &, 084 &,- 035 &,- 303 &, 763 \\
\hline
\end{tabular}

Sumber: Data primer yang diolah, 2022

Uji glejser adalah salah satu uji yang dapat digunakan untuk pengujian heterokedastisitas. Syarat peng ujian yakni nilai Sig > 0,05. Hasil dari pengujian pada Tabel 8 menunjukkan bahwa nilai Sig X sebesar 0,778 > 0,05 dan nilai Sig Z sebesar 0,763 > 0,05 sehingga model regresi dikatakan terbebas dari masalah heterokedastisitas.

Pengujian Hipotesis

Moderated Regression Analysis digunakan dalam penelitian ini untuk menguji hipotesis yang telah ditentukan. Berikut rumus moderated regression dalam penelitian ini:

$$
Y=a+b_{1} X_{1}+b_{2} Z+b_{3}\left|X_{1}-Z\right|+e
$$


Keterangan :

Y :Persepsi Wajib Pajak

$\mathrm{X}$ :Program Pengungkapan Sukarela

$\mathrm{Z}$ :Kepercayaan Terhadap Pemerintah

$\mathrm{a}$ :Konstanta

$\mathrm{b}:$ Koefisien regresi

e :eror term

Hipotesis 1: Program Pengungkapan Sukarela berpengaruuh terhadap Persepsi Wajib Pajak

Uji T Parsial

Tabel 9. Hasil Uji T Parsial Hipotesis 1

\begin{tabular}{|l|l|r|r|r|r|r|}
\hline \multicolumn{2}{|l|}{ Model } & \multicolumn{2}{|c|}{ Unstandardized Coefficients } & Standardized Coefficients & \multirow{2}{*}{ t } & \multirow{2}{*}{ Sig. } \\
\cline { 3 - 6 } & B & Std. Error & & \\
\hline 1 & (Constant) & 31,190 & 2,962 & & 10,531 &, 000 \\
\hline & X & 1,006 &, 144 &, 549 & 6,984 &, 000 \\
\hline
\end{tabular}

Sumber: Data primer yang diolah, 2022

Hasil pengujian pada Tabel 9 menunjukkan nilai signifikansi variabel X (Program Pengungkapan Sukarela) sebesar 0,000 < 0,05. Atas hal ini, variabel Program Pengungkapan Sukarela (X) secara statistik memiliki pengaruh terhadap variabel Persepsi Wajib Pajak (Y). Nilai Beta 1,006 menunjukkan pengaruh yang positif. Atas hal ini Hipotesis 1 dinyatakan diterima.

Uji Koefisien Determinasi ( R square)

Tabel 10. Hasil Uji R Square Hipotesis 1

\begin{tabular}{|l|r|r|r|r|}
\hline Model & R & Rquare & $\begin{array}{l}\text { Isted R Square of the } \\
\text { Estimate }\end{array}$ \\
\hline &, $549^{\mathrm{a}}$ &, 302 &, 295 & 4,74884 \\
\hline
\end{tabular}

Sumber: Data primer yang diolah, 2022

Hasil pengujian pada Tabel 10 menunjukkan nilai $R$ Square sebesar 0,302 atau 30,2\%. Hal ini menunjukkan bahwa sebesar 30,2\% variabel Persepsi Wajib Pajak dipengaruhi oleh variabel Program Pengungkapan Sukarela. Sisanya sebesar 69,8\% dipengaruhi oleh variabel lain diluar penelitian ini.

Hipotesis 2 : Kepercayaan Terhadap Pemerintah dapat memperkuat pengaruh Program Pengungkapan Sukarela terhadap Persepsi Wajib Pajak

Uji T Parsial

Tabel 11. Hasil Uji T Parsial Hipotesis 2

\begin{tabular}{|l|l|r|r|r|r|r|}
\hline \multirow{2}{*}{ Model } & \multicolumn{2}{c|}{$\begin{array}{c}\text { Unstandardized } \\
\text { Coefficients }\end{array}$} & $\begin{array}{l}\text { Standardize } \\
\text { d Coefficients }\end{array}$ & \multicolumn{1}{c|}{ T } & \multirow{2}{*}{ Sig. } \\
\cline { 2 - 5 } & \multicolumn{1}{|c|}{ B } & \multicolumn{1}{c|}{ Std. Error } & \multicolumn{1}{c|}{ Beta } & \\
\hline 1 & (Constant) & 6,892 & 10,438 & &, 660 &, 510 \\
\hline & X & 1,801 &, 540 &, 983 & 3,332 &, 001 \\
\hline & Z & 1,781 &, 595 & 1,231 & 2,992 &, 003 \\
\hline & X_Z &,- 065 &, 029 & $-1,377$ & $-2,240$ &, 027 \\
\hline
\end{tabular}

Sumber: Data primer yang diolah, 2022 
Hasil pengujian pada Tabel 11 menunjukkan nilai signifikansi variabel X (Program Pengungkapan Sukarela) yang dimoderasi variabel Z (Kepercayaan Terhadap Pemerintah) sebesar 0,027 < 0,05. Sehingga variabel Program Pengungkapan Sukarela (X) yang dimoderasi variabel Kepercayaan Terhadap Pemerintah (Z) secara statistik memiliki pengaruh terhadap variabel Persepsi Wajib Pajak (Y). Nilai Beta -0,065 menunjukkan pengaruh yang negatif.

\section{Uji Koefisien Determinasi ( R square)}

\section{Tabel 12. Hasil Uji R Square Hipotesis 2}

\begin{tabular}{|l|r|r|r|r|}
\hline Model & R Square & Isted R Square & $\begin{array}{l}\text { l. Error of the } \\
\text { Estimate }\end{array}$ \\
\hline &, $633^{\mathrm{a}}$ &, 401 &, 385 & 4,43767 \\
\hline
\end{tabular}

Sumber: Data primer yang diolah, 2022

Hasil pengujian pada Tabel 12 menunjukkan nilai $R$ Square sebesar 0,401 atau 40,1\%. Hal ini menunjukkan peningkatan dari pengujian sebelumnya pada H1. Peningkatan nilai $R$ Square menunjukkan bahwa adanya penguatan dari variabel Z (Kepercayaan Terhadap Pemerintah) terhadap model regresi, sehingga dapat disimpulkan bahwa terjadi penguatan sebesar 40,1\% terhadap hubungan antara variabel Persepsi Wajib Pajak dan Program Pengungkapan Sukarela. Atas hal ini Hipotesis 2 dinyatakan diterima.

\section{PEMBAHASAN}

Pengaruh Program Pengungkapan Sukarela Terhadap Persepsi Wajib Pajak

Berdasarkan hasil analisis menunjukkan bahwa Program Pengungkapan Sukarela berpengaruh terhadap Persepsi Wajib Pajak yang tercermin dalam hasil pengujian dalam model moderated regression analysis. Hal ini sebanding dengan penelitian terdahulu oleh Aruan et al. (2017) yang menjelaskan bahwa adanya pengaruh dari tax amnesty terhadap persepsi wajib pajak. Pengaruh tersebut berasal dari tujuan dan manfaat dilaksanakannya tax amnesty yang ditunjukkan dengan sikap positif/setuju dari wajib pajak atas terlaksananya kebijakan tax amnesty. Wajib pajak setuju bahwa tax amnesty akan meningkatkan penerimaan pajak yang berguna untuk memulihkan kondisi ekonomi Indonesia. Pernyataan ini selaras dengan salah satu tujuan dilaksanakannya Program Pengungkapan Sukarela (Tax Amnesty Jilid II) yang tercermin dalam pernyataan wawancara Narasumber 2 yang menjelaskan:

"Saat ini negara membutuhkan dana yang akan digunakan untuk menangani dampak pandemi Covid-19, sehingga Program Pengungkapan Sukarela merupakan salah satu upaya untuk meningkatkan penerimaan tersebut".

Pengetahuan, pengamatan, dan pengalaman merupakan faktor internal dalam teori atribusi yang dapat dijadikan salah satu acuan wajib pajak dalam menentukan persepsinya terkait Program Pengungkapan Sukarela, seperti yang dijelaskan dalam penelitian Alfiyah \& Latifah (2017) wajib pajak dapat belajar melalui pencarian informasi terkait kebijakan tersebut, ikut serta penyuluhan/sosialisasi terkait kebijakan tersebut, serta pengamatan langsung dan pengalaman untuk dapat mengetahui manfaat atas kebijakan tersebut. Program Pengungkapan Sukarela dilaksanakan untuk memberikan pilihan bagi wajib pajak untuk mengungkapkan hartanya yang belum terlapor di SPT Tahunan dengan membayar sesuai dengan tarif yang telah ditetapkan.

Berdasarkan skema atau mekanisme yang telah dikeluarkan, kebijakan ini memberikan keuntungan bagi wajib pajak yang sebelumnya telah mengikuti Tax Amnesty Jilid I yaitu dengan memperkenankan kembali untuk ikut serta dalam Program Pengungkapan Sukarela (Tax Amnesty Jilid II). Hal ini tentu merupakan suatu kesempatan yang dapat dimanfaatkan oleh wajib pajak tersebut terlebih wajib pajak yang sebelumnya telah mengikuti Tax Amnesty Jilid I dinilai memiliki pengalaman lebih sehingga dapat dijadikan gambaran untuk ikut serta kembali dalam Program Pengungkapan Sukarela. Keberadaan Program Pengungkapan Sukarela merupakan kesempatan langka yang mungkin tidak akan terjadi kembali di masa depan. Hal ini didukung oleh pernyataan wawancara Narasumber 1 yang menjelaskan:

"Program Pengungkapan Sukarela merupakan kesempatan terakhir bagi wajib pajak untuk membenahi kewajiban perpajakannya yang masih belum benar". 
Atas hal ini, penting sekali bagi wajib pajak untuk dapat memanfaatkan kebijakan Program Pengungkapan Sukarela yang telah dikeluarkan oleh pemerintah. Berdasarkan theory of planned behavior kebijakan Program Pengungkapan Sukarela dapat juga dikatakan meningkatkan kepatuhan wajib pajak yang tercermin melalui dorongan norma subjektif dan kewajiban moral. Hal ini didukung dengan penelitian terdahulu oleh Suliyawanti (2018) menjelaskan bahwa penunjang wajib pajak mengikuti tax amnesty yakni norma subjektif dan kewajiban moral. Hasil dari kuesioner yang disebarkan menunjukkan bahwa pengaruh norma subjektif khususnya dari pegawai pajak dapat memberikan pengaruh kepada wajib pajak untuk mengikuti Program Pengungkapan Sukarela, sedangkan jika kewajiban moral yang tinggi telah dimiliki oleh wajib pajak maka wajib pajak akan cenderung mengikuti Program Pengungkapan Sukarela. Hal ini didukung dengan pernyataan wawancara dari Narasumber 1 dan 2 yakni:

"Wajib pajak yang patuh adalah wajib pajak yang melaksanakan kewajiban perpajakannya dengan baik, sesuai aturan yang berlaku, serta apa adanya tanpa ada yang ditutupi".

Dengan demikian, Kebijakan Program Pengungkapan Sukarela memiliki pengaruh terhadap Persepsi Wajib Pajak dalam menjalankan kewajiban perpajakannya. Wajib pajak menilai kebijakan Program Pengungkapan Sukarela merupakan salah satu strategi negara dalam pemulihan ekonomi pasca pandemi Covid-19.

Pengaruh Kepercayaan Terhadap Pemerintah memperkuat hubungan antara Program Pengungkapan Sukarela dan Persepsi Wajib Pajak

Berdasarkan hasil analisis menunjukkan bahwa Kepercayaan Terhadap Pemerintah memperkuat hubungan antara Program Pengungkapan Sukarela terhadap Persepsi Persepsi Wajib Pajak yang tercermin dalam hasil pengujian dalam model moderated regression analysis yang dapat disimpulkan bahwa Kepercayaan Terhadap Pemerintah memiliki pengaruh negatif dalam memperkuat hubungan antara Program Pengungkapan Sukarela dan Persepsi Wajib Pajak.

Salah satu faktor pendorong utama wajib pajak untuk mematuhi kewajiban perpajakannya yaitu kepercayaan terhadap pemerintah. Hal tersebut sesuai dengan hasil penelitian yakni kepercayaan terhadap pemerintah memperkuat hubungan Program Pengungkapan Sukarela terhadap Persepsi Wajib Pajak. Berdasarkan teori atribusi, kepercayaan terhadap pemerintah termasuk dalam faktor eksternal yang dapat memperkuat hubungan Program Pengungkapan Sukarela dan Persepsi Wajib Pajak. Penguatan kepercayaan ini sejalan dengan pernyataan wawancara dari Narasumber 4 yang menjelaskan:

"Pemerintah telah berusaha untuk menyusun sistem yang adil dan sebagai wajib pajak mau tidak mau harus mempercayai hal tersebut, karena perpajakan merupakan kewajiban sebagai warga negara dengan tujuan yang baik, sehingga harapannya para pihak berwenang dapat menjalankan amanah tersebut".

Atas hal tersebut sebanding dengan penelitian Francis (2019) yang menjelaskan bahwa dengan pemerintah memperkuat lembaga-lembaga negara yang berwenang dalam perpajakan akan dapat memberantas kecurangan (korupsi) dan menghasilkan pemerintahan yang transparan serta akuntanbilitas. Implementasi penguatan lembaga-lembaga negara ini tercermin dalam pernyataan wawancara dari Narasumber 2 yang menjelaskan:

"Saat ini perpajakan terus melakukan upaya reformasi birokrasi, baik terhadap aturan, sistem, maupun SDM. Tujuan yang ingin dicapai adalah perpajakan yang adil dan petugas pajak yang berintegritas".

Selain itu, hasil pengujian juga selaras dengan theory of planned behavior yang dapat disimpulkan bahwa penguatan hubungan yang dihasilkan oleh tingkat kepercayaan terhadap pemerintah akan semakin mempengaruhi persepsi wajib pajak untuk mengikuti Program Pengungkapan Sukarela (Sipahutar \& Siringoringo, 2019). Berdasarkan kuesioner yang telah disebar menunjukkan bahwa sebagian besar wajib pajak percaya bahwa kebijakan Program Pengungkapan Sukarela yang telah dirancang oleh pemerintah merupakan kebijakan yang tepat untuk dilaksanakan. Hal tersebut selaras dengan pernyataan wawancara dari Narasumber 3 yang menjelaskan:

“ Wajib pajak akan patuh pada aturan maupun kebijakan negara yang telah dikeluarkan oleh pemerintah, meskipun cenderung merasa terpaksa. Namun, keterpaksaan tersebut bukanlah halangan wajib pajak untuk tidak mematuhi kebijakan yang dikeluarkan".

Tingkat kepercayaan yang tinggi akan mendukung persepsi wajib pajak untuk memiliki kesadaran yang berujung pada komitmen yang kuat untuk memenuhi seluruh kewajiban perpajakannya. Dengan demikian, adanya variabel moderasi Kepercayaan Terhadap Pemerintah memperkuat hubungan Program Pengungkapan Sukarela terhadap Persepsi Wajib Pajak 
karena dinilai pemerintah telah berupaya untuk menciptakan sistem perpajakan yang adil serta tepat guna bagi bangsa dan negara.

\section{PENUTUP}

Kesimpulan

Dari hasil penelitian, dapat disimpulkan bahwa: Program Pengungkapan Sukarela memiliki pengaruh positif terhadap Persepsi Wajib Pajak, dan Kepercayaan Terhadap Pemerintah sebagai variabel moderasi dapat memperkuat hubungan antara Program Pengungkapan Sukarela terhadap Persepsi Wajib Pajak.

\section{Implikasi}

Penelitian yang telah dilakukan menunjukkan hasil bahwa program pengungkapan sukarela berpengaruh terhadap persepsi wajib pajak serta kepercayaan terhadap pemerintah dapat memperkuat hubungan tersebut. Implikasi atas hasil penelitian ini dapat dijadikan salah satu referensi oleh pemerintah khususnya Direktorat Jenderal Pajak dalam mengevaluasi pencapaian keberhasilan program pengungkapan sukarela berdasarkan pandangan wajib pajak. Wajib pajak cenderung akan mengikuti kebijakan jika bermanfaat serta menguntungkan bagi mereka. Hal ini juga tidak terlepas dari jaminan rasa aman dan keadilan yang harus diberikan pemerintah kepada wajib pajak. Selain itu, implikasi yang diharapkan yakni dapat meningkatkan kepatuhan wajib pajak untuk memenuhi kewajiban perpajakannya. Pemerintah telah mengeluarkan kebijakan yang memberikan keringanan kepada wajib pajak yang belum patuh untuk dapat segera patuh pajak sehingga akan meningkatkan penerimaan negara dan tujuan akan kebijakan ini dapat tercapai.

\section{Saran}

Saran untuk peneliti selanjutnya yakni dapat melakukan penelitian dengan membedakan antara responden yang telah melaksanakan Program Pengungkapan Sukarela dan responden yang tidak melaksanakan Program Pengungkapan Sukarela serta penelitian juga dapat dilakukan dengan objek yang berbeda dengan menambah responden atau menambah variabel maupun mengganti variabel dengan yang lainnya.

\section{DAFTAR PUSTAKA}

Ajzen, I. (1991). The theory of planned behavior. Organizational Behavior and Human Decision Processes, 50(2), 179-211. https://doi.org/10.1016/0749-5978(91)90020-T

Alfiyah, N., \& Latifah, S. W. (2017). Pengaruh pelaksanaan pebijakan sunset policy , tax amnesty, kepatuhan wajib pajak. Jurnal Reviu Akuntansi Dan Keuangan, 7(2), 1081-1090.

Ariesta, R. P., \& Latifah, L. (2017). Pengaruh kesadaran wajib pajak , sanksi perpajakan , sistem administrasi perpajakan modern , pengetahuan korupsi , dan tax amnesty terhadap kepatuhan wajib pajak. Akuntansi Dewantara, 1(2), 173-187.

Aruan, R., Sujana, I. N., \& Tripalupi, L. E. (2017). Persepsi Wajib Pajak Terhadap Pelaksanaan Program Tax Amnesty Di Kantor Pelayanan Pajak (Kpp) Pratama Singaraja Tahun 2016-2017. Jurnal Pendidikan Ekonomi Undiksha, 9 (2), 417. https://doi.org/10.23887/jjpe.v9i2.20113

BPS. (2020). Keadaan Ketenagakerjaan Indonesia Agustus 2020. Badan Pusat Statistik, XXiI, 05 N(91), 1-20.

Dewi, N. P. D. A., \& Diatmika, I. P. G. (2020). Pengaruh Tingkat Kepercayaan, Persepsi Tax Amnesty, Akuntabilitas Pelayanan Publik, dan Lingkungan Sosial terhadap Kepatuhan Wajib Pajak Orang Pribadi. Jurnal Ilmiah Akuntansi Dan Humanika, 10(2), 245. https://doi.org/10.23887/jiah.v10i2.25895

Doğan Bozdoğan, T. Ş. (2018). An Empirical Analysis of The Impact of Tax Amnesties on Tax Incomes Between $1980-2014$ In Turkey. International Journal of Eurasia Social Sciences, 9(32), 1036-1046. Retrieved from https://www.researchgate.net/publication/326273397

Draft Rancangan Umum Tentang Harmonisasi Peraturan Perpajakan. (2021).

Francis, 0. (2019). The influence of tax amnesty programme on tax compliance in Nigeria: The moderating role of political trust. Journal of Accounting and Taxation, 11(7), 120-129. https://doi.org/10.5897/jat2019.0349

Irawati, W., \& Sari, A. K. (2019). Pengaruh Persepsi Wajib Pajak Dan Preferensi Risiko Terhadap Kepatuhan Wajib Pajak. Jurnal Akuntansi Barelang, 3(2), 104. https://doi.org/10.33884/jab.v3i2.1223 
Janna, N. M. (2020). Konsep Uji Validitas dan Reliabilitas dengan Menggunakan SPSS. Artikel : Sekolah Tinggi Agama Islam (STAI) Darul Dakwah Wal-Irsyad (DDI) Kota Makassar, (18210047), 1-13.

Ketut, N., Ambara, D., \& Noviari, N. (2017). Faktor - Faktor Yang Mempengaruhi Kemauan Wajib Pajak Menjadi Peserta Amnesti Pajak. 20, 585-614.

Masdi, A. (2021, June). Menakar Penerimaan Pajak di Tahun Pandemi. Kementerian Keuangan Republik Indonesia. Retrieved from https://www.kemenkeu.go.id/publikasi/artikel-dan-opini/menakar-penerimaan-pajak-di-tahun-pandemi/

oleh Menteri Keuangan Republik Indonesia. (2021). Sosialisasi Undang-Undang HarmonisasI. (November).

Purnamasari, A., Pratiwi, U., \& Sukirman, S. (2018). Pengaruh Pemahaman, Sanksi Perpajakan, Tingkat Kepercayaan Pada Pemerintah Dan Hukum, Serta Nasionalisme Terhadap 22 Kepatuhan Wajib Pajak Dalam Membayar PBB-P2 (Studi Pada Wajib Pajak PBB-P2 di Kota Banjar). Jurnal Akuntansi Dan Auditing, $14(1)$, 22. https://doi.org/10.14710/jaa.v14i1.18221

Sipahutar, K. S., \& Siringoringo, W. (2019). Pengaruh Peraturan Perpajakan , Sosialisasi , dan Kepercayaan atas Sistem Perpajakan terhadap Kemauan Pelaksanaan Tax Amnesty ( Studi Empiris Wajib Pajak Orang Pribadi di Kabupaten Bekasi ) Intisari. JAAF (Journal of Applied Accounting and Finance), 3(2), 163-179.

Suliyawanti, E. (2018). Faktor-Faktor Yang Mempengaruhi Wajib Pajak Untuk Mengikuti Tax Amnesty (Studi Kasus pada Wajib Pajak yang Terdaftar di KPP Sleman). Thesis Program Studi Magister Akuntansi Universitas Islam Indonesia.

Suyanto, S., \& Putri, I. S. (2017). Pengaruh Persepsi Wajib Pajak Tentang Kebijakan Tax Amnesty (Pengampunan Pajak), Dan Motivasi Membayar Pajak Terhadap Kepatuhan Perpajakan. Jurnal Akuntansi, 5(1), 49. https://doi.org/10.24964/ja.v5i1.256

V. Wiratna Sujarweni. (2015). SPSS Untuk Penelitian. Pustaka Baru Press.

Wijaya, R., \& Febrianti, M. (2021). Faktor-faktor yang berpengaruh terhadap kepatuhan wajib pajak orang pribadi. Trisakti School of Management. 